\title{
Could Sputum Eosinophilia Act as a Predictive Test for Diagnosis of High Risk Bakery Workers
} to Asthma?

\author{
Omid Giahi1,2, Mehrzad Ebrahemzadih1,2, Jamshid Khoubi1,2* \\ ${ }^{1}$ Kurdistan Environmental Health Research Center, Kurdistan University of Medical Sciences, Sanandaj, Iran \\ ${ }^{2}$ Department of Occupational Health, Faculty of Health, Kurdistan University of Medical Sciences, Sanandaj, \\ Iran \\ Email: ${ }^{*}$ jamshidkhoubi@muk.ac.ir
}

Received 28 December 2014; accepted 10 January 2015; published 20 January 2015

Copyright (C) 2015 by authors and Scientific Research Publishing Inc.

This work is licensed under the Creative Commons Attribution International License (CC BY).

http://creativecommons.org/licenses/by/4.0/

(c) (i) Open Access

\section{Abstract}

Background: Occupational flour inhalation has been a culprit in the start of several pulmonary diseases such as asthma. We examined the relationship between occupational wheat flour inhalation in bakery and supermarket employees with pulmonary functions, respiratory symptoms, and sputum eosinophilia to determine hyper-responsiveness in a cross-sectional study in Iran. Methods: 122 subjects from traditional bakeries and 137 subjects from supermarket employees were enrolled in the study. Flour exposure concentrations, respiratory signs, sputum analysis, and respiratory volumes and capacities were measured based on the standard methods. Results: Respirable concentration of flour in the bakery workers was two- to four-fold of ACGIH's threshold limit value in which bread-bakers with $2.2 \mathrm{mg} / \mathrm{m}^{3}$ experienced maximum exposures. The supermarket employees were not exposed to flour dust. The respiratory volumes in both bakery and supermarket employees were in the normal range. However, the median of voluminal percentage in bakery workers except Forced Vital Capacity (FVC) decreased $(p<0.001)$. The mean respiratory volume of bread-bakers was reduced compared to supermarket employees $(p<0.05)$. In addition, we observed increased respiratory symptoms in the bakery workers, again more prevalent in the bread-bakers. There was a significant correlation between flour exposure concentration and sputum eosinophilia in which the percentage of eosinophilia in the bread-bakers was more than other bakery and supermarket employees. Although there were reductions in the respiratory volumes, the results indicated no obstructive spirometric pattern. Conclusions: Sputum eosinophilia might be a suitable screening method to detect airway hyper-responsiveness in workers exposed to

\footnotetext{
"Corresponding author.
} 


\title{
known asthmogens.
}

\section{Keywords}

\author{
Bakery Workers, Hyper-Responsiveness, Pulmonary Function Tests, Sputum Eosinophilia, \\ Wheat Flour
}

\section{Introduction}

Flour is a mixture of organic materials, which can be produced by milling of a wide variety of cereals such as wheat, barley, corn, etc. The most common flour is wheat flour, which is a mixture of various foodstuffs with wide usage in industrial production. The flour dust inhalation occurs in several industries and occupations such as flour factories, confectioneries, and also bakeries [1] [2].

Wheat flour can be an allergen and induce a wide variety of allergic disorders [3]-[5]. According to the report of Center for Disease Control and Prevention (CDC), the inhalation of flour organic particles is one of the important factors that can cause allergic and chronic respiratory disorders [1] [6]-[8]. Dose-response epidemiological studies clearly demonstrated that exposure to flour particles is one of the most determining factors in airway hyper-responsiveness and allergic diseases such as occupational asthma (OA) [1] [7] [9].

Allergens can cause OA which is essentially immunological. Usually OA does not display a sudden manifestation and a latent period is needed for sensitization. This period usually lasts for several months or more following the first exposure to a causative allergen.

To demonstrate that $\mathrm{OA}$ is produced by high molecular mass agents, we need evidence of specific IgE sensitization that it should be confirmed with a greatly sensitive test. Lack of such evidence significantly rules out the diagnosis.

Patients who are sensitized to high molecular mass agents almost always complain of accompanying symptoms such as rhinitis, itching and watering of the eyes and sometimes an urticarial rash [10].

Identification of hypersensitivity to high-molecular weight allergens can play an important role in prevention of occupational asthma [1] [7] [9] [11]-[13].

Sub-clinical stages of asthma can start before clinical signs, and changes in respiratory volumes and capacities. Therefore, it is obvious that early diagnosis of at risk cases in subclinical stages can reduce disease burden [7].

To diagnose IgE-mediated occupational allergic diseases, we can use skin prick testing (SPT), in order to detect sensitized patients like asymptomatic bakers and symptomatic bakers with nasal and/or respiratory symptoms at work. We can detect sub-clinical stages of asthma by this procedure [14] [15].

Although various methods have been applied for the diagnosis of airway hyper-responsiveness, such as SPT, few cheap and simple methods have been introduced so far. Having such tests may help to identify susceptible cases and prevent occurrence of excessive occupational asthma cases. It is specifically useful for the deprived areas or developing regions that have no access to simple tests such as SPT.

In allergic respiratory pathogenesis, eosinophil cells are among the most important inflammatory cells, which are influential in the onset and susceptibility of individuals to the illness [12]. Sputum eosinophilia, meanwhile, is one of the suitable diagnostic tests that have more than 80 percent sensitivity and 95 percent specificity [13].

Sufficient evidence is available now showing that induced sputum is the best and most complete method for noninvasive examination of airway inflammatory infections due to its favorable properties including reliability, reproducibility, and responsiveness. Furthermore, the findings of some recent investigations have reliably demonstrated that induced sputum is a significant instrument for the determination of the phenotype of asthma, COPD, and other airway disorders, and also for examining the effect of treatment of these ailments.

The two cell types that are most frequently applied to describe the inflammatory response of the airways are eosinophils and neutrophils and the proportion of them which is essential to understand the result of this test. It is possible to monitor the pattern of inflammation more adequately in specific respiratory disorders by the use of induced sputum along with pulmonary function tests [16]-[19].

In Iran, there are about 58,000 traditional bakery units with over 250,000 workers. The prevalence of respiratory and pulmonary diseases, specifically asthma, is increasing in Iran among the workers of these professions. 
About 15 percent of traditional bakery areas are less than $30 \mathrm{~m}^{2}$ and large populations are exposed to potential allergic factors [20].

In this study, we aimed at examining the relationship between occupational wheat flour inhalation and pulmonary functions, respiratory symptoms, and sputum eosinophilia of bakery and supermarket employees in Sanandaj, Kurdistan, Iran.

\section{Materials and Methods}

This cross-sectional study was carried out on traditional bakeries and supermarkets in Iran. In fact, there were about 396 bakeries in Sanandaj. First, indoor air was sampled in all bakeries to determine wheat flour dust concentration. Based on evidence available at professional and environmental health centers of the university and the recorded documents, the rate of exposure has been greater in the past compared to present.

Those workers whose flour dust concentrations were more than 0.5 milligrams per cubic meter $\left(\mathrm{mg} / \mathrm{m}^{3}\right)$ in their work environment, including 85 bakeries, participated in the study. The $0.5 \mathrm{mg} / \mathrm{m}^{3}$ is the threshold limit value (TLV) for wheat flour dust exposure in bakery workers [7]. We selected bakery workers based on the following criteria: 1) continuous past record of at least 3 years and working 6 hours per day in the current occupation, 2) absence of drug abuse in the recent month, and 3) exposure to flour dust. After applying these criteria, 50 bakeries were randomly selected and 140 workers enrolled. The working period of the bakeries was from 5 AM to 3 PM. A total of 158 supermarket workers from similar geographical region with psychosocial characteristics closely similar to the bakeries were randomly assigned to the non-exposure group. Based on environmental measurements, these individuals had no exposure to flour dust.

Informed written consent was obtained from all participants. Moreover, the study was approved by the appropriate ethics committee and has therefore been performed in accordance with the ethical standards laid down in the 1964 Declaration of Helsinki and its later amendments. Finally, data measurement was done from June 2012 to August 2013.

\subsection{Air Sampling}

Personal sampling was done in each bakery to determine 8-hour Time Weighted Average (TWA) concentration. In other words, air sampling was carried out for respirable flour dust during working shift. The sampling and analyses were based on 0600 standard methods of NIOSH [21]. Respirable dust samples were collected using a personal sampling pump (SKC-224-PCXR4 model) located in the worker's breathing zone and $10 \mathrm{~mm}$ cyclone at $1.7 \mathrm{l} / \mathrm{min}$ flow rate. The dust samples mass was weighted using a calibrated Sartorius balance (i.e. before and after sampling). In order to obtain accurate results, all filters were preserved in desiccator prior to weighting for 24h. Furthermore, a blank sample filter cassette assembly was provided for every four samples to increase the accuracy of sampling. The flour dust concentrations, thereafter, were calculated in $\mathrm{mg} / \mathrm{m}^{3}$.

\subsection{Questionnaire}

Allergic and respiratory symptoms in the bakery and supermarket employees were examined by the new Medical Research Council (MRC) respiratory symptoms questionnaire that has a high sensitivity (65\% - 91\%) and specificity (85\% - 96\%) [22]-[24]. This tool has several new questions for identification of asthma and bronchial hyper-responsiveness [25]. Respiratory symptoms include chronic coughs, chronic sputum, wheezing in the last two years, past record of asthma attacks, and allergic symptoms during and after work. Breathing problems include difficulty in breathing when a person enters a cold, warm, frosty, misty or smoky environment or during cooking in the closed places. Allergic symptoms include symptoms of rhinitis, itching and watering of the eyes and sometimes an urticarial rash, sneezing, itching, and dyspnea during or after touching the materials in the work environment. Smoke status, meanwhile, was classified into three groups: 1) active smoker, 2) neversmoker, and 3): environmental tobacco smoke (ETS-smokers). Smoking was defined based on pack per year.

\subsection{Spirometry}

Evaluating dynamic lung functions are more important than static volumes. One of the most important useful tools for the diagnosis of occupational respiratory diseases is spirometry. In addition, results of spirometry are beneficial as they can help to diagnose early pulmonary dysfunctions. We did serial spirometry before, during, 
and after work in bakery workers based on the American Thoracic Society Scales, and only during work for supermarket employees using Spirolab III, MIR, Italy device [26].

This device was calibrated on a daily basis and operated within the ambient temperature range of $20^{\circ} \mathrm{C}-25^{\circ} \mathrm{C}$. We educated all participants about the test procedure. Participants were noticed to stop smoking 1 hour before test. A nose clip was used to carry out the test while the subject was in the sitting position. The test was performed three times after sufficient rest and the results were obtained in the spirometer. The readings of spirometer were expressed as percentages of the predicted values according to current guidelines [27]. We provided important parameters, such as Forced Vital Capacity (FVC), forced expiratory volume in second $1\left(\mathrm{FEV}_{1}\right)$, peak expiratory flow rate (PEF), and forced expiratory flow 25 - $75\left(\mathrm{FEF}_{25-75}\right)$.

\subsection{Sputum Processing}

Induction of the sputum was carried out by ultrasonic nebulizer and the use of aerosolized $\mathrm{NaCl} 4.5 \%$ in flow rate of $1.5 \mathrm{ml} / \mathrm{min}$ for three stages of five minutes. Then, the participants washed their mouth with water and dried it by a Kleenex after each inhalation to prevent salivary contamination. After this stage, the induced sputum was poured into a clean plastic dish by coughing up and samples were kept in $4^{\circ} \mathrm{C}$ until the test time. For safety reasons and predicting the respiratory problems with $\mathrm{NaCl}$, PEF was measured in participants after every five minutes. If it was more than $250 \mathrm{l} / \mathrm{min}$, the test was continued [12]. Next, the samples were transferred to the laboratory.

Our specimens were represented as acceptable if alveolar macrophages were discovered and the percentage of squamous cells was less than $10 \%$ among nucleated cells. Also, sputum was transmitted to the slides in small amounts and smoothly and evenly spread over two microscopic slides. Then, they were smeared. Next, each of the smears was air-dried and stained using the May-Grunwald-Giemsa method. Moreover, differential cell counts were done by an observer who was blind to the clinical features of the participants. Finally, the eosinophil count was expressed as a percentage of the total cell count which is a more accurate measure compared to absolute count [28].

\subsection{Statistical Methods}

After data collection, the normality of distribution of data was tested by One Sample K-S in SPSS IBM 21 software. Then, relevant data were analyzed using Independent T-tests (for normal distribution of data), Chi-square, One-way ANOVA and Mantel Hansel (for non-normal distribution of data). The latter test was used to control the effect of confounding factors.

\section{Results}

The means of age and working experience were 34.7 and 15.5 years for the exposure group, and 33.7 and 10.5 years for the non-exposure group, respectively.

Explanation of job titles and demographic characteristics of bakery and supermarket employees are tabulated in Table 1 and Table 2, respectively.

A total of 259 participants received sputum induction. Also, 86.8\% of cases of sputum induction were done successfully. The differential cell counts expressed as percentage values, and also the upper limits for each cell type are displayed in Table 3. As the table shows it, macrophages and neutrophils were more abundant. Additionally, few lymphocytes and bronchial epithelial cells were observed. As can be seen, eosinophil counts were higher in bakery subjects $(n=22)$ compared to supermarket employees $(n=5)$. This difference was clinically relevant and statistically significant $(p<0.001)$. Additionally, 3 participants in the bakery group and 12 in supermarket group were affected with asthma showing a statistically significant difference ( $p$-value $=0.008$ ) and mean of eosinophil count was $6.99 \pm 2.27$. As mentioned earlier, hypothesis of the authors is that before asthmatic period, exposure to flour dust may increase eosinophil count in sputum that it is according with our findings which has been shown in Table 3.

Respirable concentration of flour in bakery workers was two to four-fold of ACGIH's TLV $\left(0.5 \mathrm{mg} / \mathrm{m}^{3}\right)$, in which bread-bakers with $2.2 \mathrm{mg} / \mathrm{m}^{3}$ ( $\mathrm{SD}=3.8$ ) experienced maximum exposures. The minimum respiratory exposure concentration in bakery workers was in agents-which was $0.92 \mathrm{mg} / \mathrm{m}^{3}$. None of the workers used respiratory protection. (See Table 4 for mean respirable dust concentrations in all job titles). 
Table 1. Explanation of job titles in bakeries of Sanandaj, Kurdistan, Iran.

\begin{tabular}{cl}
\hline Job & \multicolumn{1}{c}{ Explanation } \\
\hline Bread baker & $\begin{array}{l}\text { Performing works like formation and processing of dough; bread rolling; unloading flour sacks; adding necessary } \\
\text { enzymes to the dough in mixer; and tools' dusting by flour }\end{array}$ \\
Confectioner & Bread's baking and finishing \\
Counter hand & Assistant of confectioner \\
Agent & Collecting baked bread and selling to the customer \\
\hline
\end{tabular}

Table 2. Demographic characteristics of the bakery and supermarket employees.

\begin{tabular}{|c|c|c|c|c|}
\hline \multicolumn{2}{|c|}{ Characteristic } & Unit & Bakery workers & Supermarket employees \\
\hline \multicolumn{2}{|c|}{ Participants } & Number & 122 & 137 \\
\hline \multicolumn{2}{|c|}{$\operatorname{Age}^{*, a}$} & Years & $34.7( \pm 7.9)$ & $33.7( \pm 7.6)$ \\
\hline \multicolumn{2}{|c|}{ Height $^{* *, a}$} & Centimeter & $173.1( \pm 6.9)$ & $176.4( \pm 6.6)$ \\
\hline \multicolumn{2}{|c|}{ Body weight $^{* * *, a}$} & Kilograms & $74.6( \pm 12.3)$ & $78.9( \pm 11.6)$ \\
\hline \multicolumn{2}{|c|}{ Work experience $e^{* * *, a}$} & Years & $15.5( \pm 8.4)$ & $10.5( \pm 6.9)$ \\
\hline \multicolumn{2}{|c|}{ Daily work time ${ }^{* * *, a}$} & Hours & $8.9( \pm 1.2)$ & $7.9( \pm 1.2)$ \\
\hline \multirow{3}{*}{ Smoking status } & Active smokers $^{* *}$ & Number & 26 & 8 \\
\hline & Never smokers* & Number & 88 & 126 \\
\hline & ETS smokers ${ }^{*}$ & Number & 8 & 3 \\
\hline
\end{tabular}

Abbreviations: Environmental tobacco smoke (ETS); ${ }^{*} p>0.05 ;{ }^{* *} p<0.001 ;{ }^{* * *} p=0.03 ;{ }^{\text {a }}$ Results are in mean (standard deviation).

Table 3. Sputum differential cell percentages in bakeries, supermarket employees and asthmatic ones.

\begin{tabular}{|c|c|c|c|c|c|c|c|c|c|c|c|c|}
\hline \multirow[b]{2}{*}{ Cell counts } & \multicolumn{3}{|c|}{ Mean \pm SD } & \multicolumn{3}{|c|}{ Median } & \multicolumn{3}{|c|}{$10^{\text {th }}$ percentile } & \multicolumn{3}{|c|}{$90^{\text {th }}$ percentile } \\
\hline & Bakery & Supermarket & $\begin{array}{l}\text { With } \\
\text { Asthma }\end{array}$ & Bakery & Supermarket & $\begin{array}{l}\text { With } \\
\text { asthma }\end{array}$ & Bakery & Supermarket & $\begin{array}{l}\text { With } \\
\text { asthma }\end{array}$ & Bakery & Supermarket & $\begin{array}{l}\text { With } \\
\text { Asthma }\end{array}$ \\
\hline Eosinophils & $1.76 \pm 3.96$ & $0.24 \pm 1.51$ & $6.99 \pm 2.27$ & 0.000 & 0.000 & 6.7 & 0.000 & 0.000 & 4.12 & 8.35 & 0.000 & 11.4 \\
\hline Neutrophils & $30.47 \pm 4.88$ & $22.13 \pm 5.66$ & $30.85 \pm 3.37$ & 30 & 21 & 31 & 24.3 & 14.8 & 26.6 & 38 & 30 & 36.2 \\
\hline Macrophages & $59.24 \pm 6.95$ & $68.17 \pm .01$ & $58.46 \pm 3.40$ & 59.75 & 69 & 59.5 & 50.30 & 56 & 53.2 & 68 & 80 & 62.4 \\
\hline Lymphocytes & $1.78 \pm 1.04$ & $3.36 \pm 1.89$ & $2.55 \pm 0.72$ & 2.0 & 3.0 & 2.8 & 0.000 & 1.0 & 1.6 & 3.0 & 6.0 & 3.4 \\
\hline Epithelia cells & $1.88 \pm 1.26$ & $5.02 \pm 3.21$ & $1.13 \pm 0.91$ & 2.0 & 5.0 & 1.0 & 0.000 & 1.0 & 0.000 & 4.0 & 9.0 & 2.4 \\
\hline
\end{tabular}

Table 4. Mean respirable dust concentration and association with sputum eosinophilia in all job titles of bakeries and supermarkets.

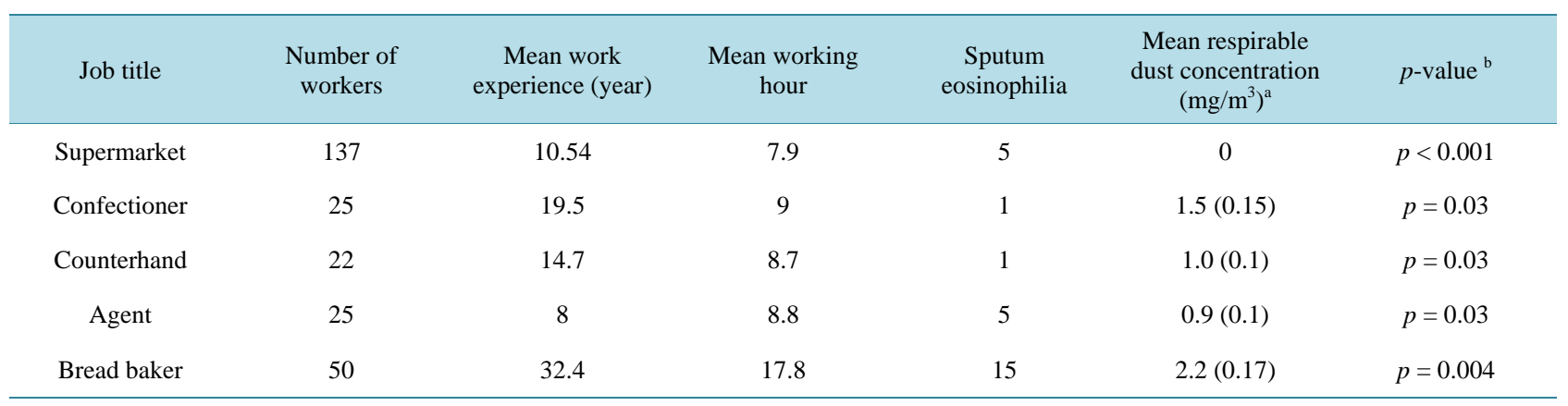

${ }^{\mathrm{a}}$ Results are in mean (standard deviation); ${ }^{\mathrm{b}} p$-value for sputum eosinophilia and mean respirable dust concentration. 
The mean FVC, $\mathrm{FEV}_{1}, \mathrm{PEF}$, and $\mathrm{FEF}_{25-75}$ of serial spirometries (before, during, and after work) in bakery workers were 95.2 ( \pm 13.1$)$, 90.3 ( \pm 12.2$)$, $89.7( \pm 6.2$ ), and 75.2 ( \pm 10.4 ), respectively; these parameters were, respectively, $97.1( \pm 6.4), 98.1( \pm 9.3), 98.8( \pm 6.1)$, and $94.6( \pm 8.3)$ in spirometry of supermarket employees (Table 5). Although the mean respiratory volumes in bakery workers were in the normal range, the median of voluminal percentage in comparison with supermarket employees, except FVC, was reduced $(p<0.001)$. There were no significant differences in serial respiratory volumes of bakery workers. Among all job titles in the bakery workers, only mean respiratory volumes of bread-bakers was significantly reduced compared to supermarket employees $(p<0.05)$.

Totally, 22 out of 122 (18\%) bakery workers and 5 out of 137 (3.6\%) supermarket employees had sputum eosinophilia $(p<0.001)$. There was a statistically significant correlation between flour exposure concentration and sputum eosinophilia in bakery workers, in which 15 out of 22 (68\%) eosinophilia specimens belonged to bread-bakers (Table 3). In addition, there was a significant difference between job titles in bakery workers and eosinophilia cells $(p=0.03)$. However, there were no significant associations between working hours or years of working and eosinophilia.

The findings of our study also revealed significant differences in respiratory symptoms including productive cough, dyspnea and wheezing between bakery and supermarket employees, though of course, these symptoms were more prevalent in bread-bakers (Table 6).

As tabulated in Table 2, 26 out of 122 (21\%) bakers were active smokers. However, the relationship between smoking and respiratory symptoms and sputum eosinophilia was not significant $(p>0.05)$.

\section{Discussion}

In this research, we studied the impact of flour inhalation on pulmonary function, respiratory symptoms, and sputum eosinophilia of bakery and supermarket employees through a cross-sectional study. We further tried to find a predictive test for occupational asthma in sensitized individuals-sputum eosinophilia. We found that maximum time weighted average exposure was in the bread-bakers, which was four-fold of recommended TLV by ACGIH. Moreover, the minimum time weighted average exposure was in the agents $\left(0.92 \mathrm{mg} / \mathrm{m}^{3}\right)$. Smith

Table 5. Pulmonary function tests among bakery and supermarket employees.

\begin{tabular}{cccccc}
\hline \multirow{2}{*}{ Pulmonary functions } & \multicolumn{2}{c}{ Bakery workers } & \multicolumn{2}{c}{ Supermarket employees } \\
\cline { 2 - 5 } & Before work $^{\mathrm{a}}$ & During work & After work $^{\mathrm{a}}$ & Mean of three stages & Mean \pm SD \\
\hline FVC (\% predicted) & $95.2 \pm 13.1$ & $94 \pm 8.7$ & $93.4 \pm 10.6$ & $94.2 \pm 11.1$ & $97.1 \pm 6.4$ \\
FEV1 $^{*}$ (\% predicted) & $90.3 \pm 12.2$ & $89.4 \pm 7.6$ & $88.8 \pm 8.8$ & $89.5 \pm 9.2$ & $98.1 \pm 9.3$ \\
FEV1/FVC $^{*}$ (\%) & $98.1 \pm 6.4$ & $98.4 \pm 5.3$ & $98.8 \pm 5.5$ & $98.5 \pm 5.8$ & $103.6 \pm 7.7$ \\
FEF $_{25-75}{ }^{*}$ (\% predicted) & $75.2 \pm 10.4$ & $75.1 \pm 9.6$ & $74.9 \pm 9.8$ & $75.1 \pm 10.1$ & $94.6 \pm 8.3$ \\
PEF $^{*}$ (\% predicted) & $89.7 \pm 6.2$ & $90.6 \pm 6.6$ & $90.8 \pm 8.2$ & $90 \pm 7.2$ & $98.8 \pm 6.1$ \\
\hline
\end{tabular}

Forced vital capacity (FVC); forced expiratory volume in second 1 (FEV 1 ); forced expiratory flow 25 - 75 (FEF $25-75)$; peak expiratory flow rate (PEF). Data are expressed as means $\pm \mathrm{SD} ;{ }^{*} p<0.001$ for mean spirometry parameters of three stages in bakery workers and supermarket employees; ${ }^{\mathrm{a}}$ There was no difference in spirometry parameters between these three stages $(p>0.05)$.

Table 6. Prevalence of respiratory symptoms in bakery and supermarket employees.

\begin{tabular}{ccc}
\hline Respiratory symptoms & $\begin{array}{c}\text { Bakery workers, } \\
\text { out of } 122(\%)\end{array}$ & $\begin{array}{c}\text { Supermarket employees, } \\
\text { out of } 137(\%)\end{array}$ \\
\hline Allergic reactions that cause respiratory problems* $^{*}$ & $18(14.7)$ & $2(0.01)$ \\
Problem with inhalation of perfumes $^{*}$ & $23(18.8)$ & $3(0.02)$ \\
History of dyspnea $^{*}$ & $19(15.6)$ & $5(0.04)$ \\
Productive cough $^{*}$ & $26(21.3)$ & $2(0.01)$ \\
Wheezing $^{*}$ & $28(22.9)$ & $2(0.01)$ \\
\hline
\end{tabular}

$$
{ }^{*} p<0.001 \text {. }
$$


et al. (2000), studied a group of workers in milling industry of UK in which the total flour concentration was 8.1 $\mathrm{mg} / \mathrm{m}^{3}$ [29]. Also, in another research by Baatjies et al. (2010) on supermarket bakeries of South Africa, the highest exposure to flour was in confectioners $\left(1.3 \mathrm{mg} / \mathrm{m}^{3}\right)$ [30]. We believe that poor ventilation and housekeeping, small workplace size $\left(<30 \mathrm{~m}^{2}\right)$, jobs category, and season of sampling were effective parameters in measuring these exposures.

One of the most important tools for the confirmation of occupational exposure in occupational field is serial spirometry. Regarding occupational pulmonary exposure, one of the important criteria of approving occupational disease is changes in espirometric indices during the work shift [31] [32].

To date, several studies have reported worker's exposure to flour and correlated it with pulmonary function [29] [33]-[37]. In this study, although respiratory volumes in bakery workers were in normal range, it is clinically worthy to mention that the number of participants in bakery workers, which had changes of pulmonary functions above $10 \%$ in $\mathrm{PEF}, \mathrm{FEF}_{25-75}, \mathrm{FVC}$, and $\mathrm{FEV}_{1}$ were $12.7 \%, 10.9 \%, 2.7 \%$, 2.7\%, respectively. Furthermore, although we found pulmonary function $\left(\mathrm{FEV}_{1}\right.$, PEF and $\left.\mathrm{FEF}_{25-75}\right)$ of both bakery and supermarket employees were in normal range, the pulmonary function of bread-bakers exposed to much more flour dust decreased significantly $(p<0.05)$ with the consideration that this reduction might be also related to respiratory symptoms at work and/or sputum inflammation. In bread-bakers, $\mathrm{FEV}_{1}$ and $\mathrm{PEF}$ decreased by $9 \%$ and $\mathrm{FEF}_{25-75}$ decreased by $21 \%$.

Sputum eosinophilia had a correlation with flour exposure in bread-bakers and might be a suitable screening method to detect airway hyper-responsiveness in workers exposed to known asthmogens.

We have also found significant association between flour dust exposure and respiratory symptoms, such as dyspnea, wheezing, and productive cough in bakery workers $(p<0.001)$.

Induced sputum has been very useful in the investigation of eosinophilic bronchitis, a condition identified in individuals complaining of chronic cough. This condition has also been caused by exposure to occupational agents and has been labeled occupational eosinophilic bronchitis, and wheat flour exposure has been described as a cause of occupational eosinophilic bronchitis. We must consider the possibility that bakers suffering from cough at work may be affected by OCB. In addition, several studies demonstrated a correlation between flour exposure and prevalence of allergic signs [8] [38] [39]. Jacobs et al. (2008), studied 860 bakers in a Dutch population and reported increased respiratory symptoms [9]. Also, Droste et al. (2003), found more often respiratory symptoms in 246 workers from traditional and industrial bakeries [33]. Sputum eosinophilia test may be a suitable screening method to detect airway hyper-responsiveness in workers exposed to known asthmogens. SPT is considered to be a significant parameter in diagnosing IgE-mediated occupational allergic disorders. One important limitation of this study was no access to SPT in less developed regions and it was better to be compared our findings with SPT in coincident study. However, since sensitization has not been measured either against work related allergens or against common allergens, final conclusions may not be specified. By the way, we believe that more epidemiological studies are required to investigate the associations between flour dust exposure and sputum eosinophilia as a predictive factor.

\section{Conclusion}

We found that those bakery workers (bread-bakers) exposed to flour dust more than the recommended TLV compared to supermarket employees that had an increased risk of respiratory symptoms. Although there were reductions in the respiratory volumes, the results indicated no obstructive spirometric pattern. Meanwhile, more sputum eosinophilia was observed in those workers (bread-bakers) who had more occupational exposure to flour dust compared to supermarket employees.

\section{Acknowledgements}

This work was supported by Kurdistan University of Medical Sciences (grant No. 89-10-14) and University of Kurdistan (grant No. 90-06-21-26167). We also extend our sincerest gratitude to Mr. Fardin Zandsalimi for sampling and data collection.

\section{Authors' Contributions}

The manuscript was written through contributions of all authors. All authors have given approval to the final 
version of the manuscript.

\section{Conflict of Interests}

Authors are not declaring any conflict of interest in this study.

\section{References}

[1] Salvatori, N., Reccardini, F., Convento, M., Purinan, A., Colle, R., De Carli, S., Garzoni, M., Lafiandra, D. and De Carli, M. (2008) Asthma Induced by Inhalation of Flour in Adults with Food Allergy to Wheat. Clinical \& Experimental Allergy, 38, 1349-1356. http://dx.doi.org/10.1111/j.1365-2222.2008.03023.x

[2] Khaniki, G.R.J., Yunesian, M., Mahvi, A.H. and Nazmara, S. (2005) Trace Metal Contaminants in Iranian Flat Breads. Journal of Agriculture \& Social Sciences, 1, 301-303.

[3] Bohadana, A., Massin, N., Wild, P., Kolopp, M. and Toamain, J. (1994) Respiratory Symptoms and Airway Responsiveness in Apparently Healthy Workers Exposed to Flour Dust. European Respiratory Journal, 7, 1070-1076.

[4] Zuskin, E., Kanceljak, B., Schachter, E.N., Godnic-Cvar, J., Mustajbegovic, J. and Budak, A. (1998) Respiratory Function and Immunological Status in Cocoa and Flour Processing Workers. American Journal of Industrial Medicine, 33, 24-32. http://dx.doi.org/10.1002/(SICI)1097-0274(199801)33:1<24::AID-AJIM4>3.0.CO;2-W

[5] Mohammadien, H.A., Hussein, M.T. and El-Sokkary, R.T. (2013) Effects of Exposure to Flour Dust on Respiratory Symptoms and Pulmonary Function of Mill Workers. Egyptian Journal of Chest Diseases and Tuberculosis, 62, 745753. http://dx.doi.org/10.1378/chest.1117241

[6] http://www.cdc.gov/niosh/docs/2003-154/method-2000.html

[7] American Conference of Governmental Industrial Hygienists (2000) Documentation of the TLVs and BEIs, 6th Edition and Supplements. ACGIH, Cincinnati.

[8] Renström, A., Mattsson, M.L., Blidberg, K., Doekes, G., Bogdanovic, J. and Tovey, E. (2006) Nasal Air Sampling for Measuring Inhaled Wheat Allergen in Bakeries with and without Facemask Use. Journal of Occupational and Environmental Medicine, 48, 948-954. http://dx.doi.org/10.1097/01.jom.0000232533.04238.3e

[9] Jacobs, J., Meijster, T., Meijer, E., Suarthana, E. and Heederik, D. (2008) Wheat Allergen Exposure and the Prevalence of Work-Related Sensitization and Allergy in Bakery Workers. Allergy, 63, 1597-1604. http://dx.doi.org/10.1111/j.1398-9995.2008.01698.x

[10] Cullinan, P. (2008) Occupational Airways Disease. Medicine, 36, 231-234. http://dx.doi.org/10.1016/j.mpmed.2008.02.008

[11] Renström, A., Mattsson, M.L., Blidberg, K., Doekes, G., Bogdanovic, J. and Tovey, E. (2006) Nasal Air Sampling for Measuring Inhaled Wheat Allergen in Bakeries with and without Facemask Use. Journal of Occupational \& Environmental Medicine, 48, 948-954. http://dx.doi.org/10.1097/01.jom.0000232533.04238.3e

[12] Louis, R., Sele, J., Henket, M., Cataldo, D., Bettiol, J., Seiden, L. and Bartsch, P. (2002) Sputum Eosinophil Count in a Large Population of Patients with Mild to Moderate Steroid-Naive Asthma: Distribution and Relationship with Methacholine Bronchial Hyperresponsiveness. Allergy, 57, 907-912. http://dx.doi.org/10.1034/j.1398-9995.2002.23608.x

[13] Brightling, C.E. (2006) Clinical Applications of Induced Sputum. Chest, 129, 1344-1348. http://dx.doi.org/10.1378/chest.129.5.1344

[14] Quirce, S. and Perales, A.D. (2013) Diagnosis and Management of Grain-Induced Asthma. Allergy, Asthma \& Immunology Research, 5, 348-356. http://dx.doi.org/10.4168/aair.2013.5.6.348

[15] Moscato, G., Pala, G., Barnig, C., De Blay, F., Del Giacco, S.R., Folletti, I., et al. (2012) EAACI Consensus Statement for Investigation of Work-Related Asthma in Non-Specialized Centres. Allergy, 67, 491-501. http://dx.doi.org/10.1111/j.1398-9995.2011.02784.x

[16] Neves Veras, T., Pizzichini, E., Steidle, L.J.M., Cinara Rocha, C., Moritz, P. and Pizzichini, M.M. (2011) Cellular Composition of Induced Sputum in Healthy Adults. Jornal Brasileiro de Pneumologia, 37, 348-353.

[17] Belda, J., Leigh, R., Parameswaran, K., O’byrne, P.M., Sears, M.R. and Hargreave, F.E. (2000) Induced Sputum Cell Counts in Healthy Adults. American Journal of Respiratory and Critical Care Medicine, 161, 475-478. http://dx.doi.org/10.1164/ajrccm.161.2.9903097

[18] Chen, D.H., Zhong, G.Y., Luo, W., Chen, O.L., Sun, B.Q., Chen, R.C., Lin, Y.N., Pan, X.A., Li, J.Y., Wu, S.Z., Lai, K.F. and Zeng, G.Q. (2013) Reference Values of Induced Sputum Cytology in Healthy Children in Guangzhou, Southern China. Pediatrics, 131, e518-e524. http://dx.doi.org/10.1542/peds.2012-0946

[19] Bandyopadhyay, A., Roy, P.P., Saha, K., Chakraborty, S., Jash, D. and Saha, D. (2013) Usefulness of Induced Sputum Eosinophil Count to Assess Severity and Treatment Outcome in Asthma Patients. Lung India, 30, 117-123. 
$\underline{\text { http://dx.doi.org/10.4103/0970-2113.110419 }}$

[20] http://mimt.gov.ir

[21] http://www.cdc.gov/niosh/docs/2003-154/method-2000.html

[22] Mirzaee, R., Kebriaei, A., Hashemi, S., Sadeghi, M. and Shahrakipour, M. (2008) Effects of Exposure to Portland Cement Dust on Lung Function in Portland Cement Factory Workers in Khash, Iran. Iranian Journal of Environmental Health Science \& Engineering, 5, 201-206.

[23] Halvani, G.H., Zare, M., Halvani, A. and Barkhordari, A. (2008) Evaluation and Comparison of Respiratory Symptoms and Lung Capacities in Tile and Ceramic Factory Workers of Yazd. Archives of Industrial Hygiene and Toxicology, 59, 197-204. http://dx.doi.org/10.2478/10004-1254-59-2008-1878

[24] Ghasemkhani, M., Kumashiro, M., Rezaei, M., Anvari, A.R., Mazloumi, A. and Sadeghipour, H.R. (2006) Prevalence of Respiratory Symptoms among Workers in Industries of South Tehran, Iran. Industrial Health, 44, 218-224. http://dx.doi.org/10.2486/indhealth.44.218

[25] Medical Research Council Committee on the Aetiology of Chronic Bronchitis (1960) Standardized Questionaries on Respiratory Symptoms. British Medical Journal, 3, 1665.

[26] Hankinson, J.L., Odencrantz, J.R. and Fedan, K.B. (1999) Spirometric Reference Values from a Sample of the General US Population. American Journal of Respiratory and Critical Care Medicine, 159, 179-187. http://dx.doi.org/10.1164/ajrccm.159.1.9712108

[27] Mohammadien, H.A., Hussein, M.T. and El-Sokkary, R.T. (2013) Effects of Exposure to Flour Dust on Respiratory Symptoms and Pulmonary Function of Mill Workers. Egyptian Journal of Chest Diseases and Tuberculosis, 62, 745753. http://dx.doi.org/10.1016/j.ejcdt.2013.09.007

[28] Hara, J., Fujimura, M., Myou, S., Kita, T., Abo, M., Katayama, N., Furusho, S., Nobata, N., et al. (2008) Sputum Eosinophilia, Airway Hyperresponsiveness and Airway Narrowing in Young Adults with Former Asthma. Allergology International, 57, 211-217. http://dx.doi.org/10.2332/allergolint.O-06-461

[29] Smith, T., Parker, G. and Hussain, T. (2000) Respiratory Symptoms and Wheat Flour Exposure: A Study of Flour Millers. Occupational medicine, 50, 25-29. http://dx.doi.org/10.1093/occmed/50.1.25

[30] Baatjies, R., Meijster, T., Lopata, A., Sander, I., Raulf-Heimsoth, M., Heederik, D. and Jeebhay, M. (2010) Exposure to Flour Dust in South African Supermarket Bakeries: Modeling of Baseline Measurements of an Intervention Study. Annals of Occupational Hygiene, 54, 309-318.

[31] Fishwick, D., Barber, C.M., Bradshaw, L.M., Harris-Roberts, J., Francis, M., Naylor, S., Ayres, J., Burge, P.S., Corne, J.M., et al. (2008) Standards of Care for Occupational Asthma. Thorax, 63, 240-250. http://dx.doi.org/10.1136/thx.2007.083444

[32] Halvani, G., Ebrahimzade, M., Hobobati, H. and Jafarinodoushan, R. (2011) Evaluation of the Respiratory Symptoms and Pulmonary Function Tests Capacities in Yazd Tile Workers. TKJ, 3, 46-53.

[33] Droste, J., Myny, K., Van Sprundel, M., Kusters, E., Bulat, P., Braeckman, L., Vermeire, P. and Vanhoorne, M. (2003) Allergic Sensitization, Symptoms, and Lung Function among Bakery Workers as Compared with a Nonexposed Work Population. Journal of Occupational \& Environmental Medicine, 45, 648-655. http://dx.doi.org/10.1097/01.jom.0000071501.96740.f7

[34] Hur, G.Y., Koh, D.H., Kim, H.A., Park, H.J., Ye, Y.M., Kim, K.S. and Park, H.S. (2008) Prevalence of Work-Related Symptoms and Serum-Specific Antibodies to Wheat Flour in Exposed Workers in the Bakery Industry. Respiratory Medicine, 102, 548-555. http://dx.doi.org/10.1016/j.rmed.2007.11.015

[35] Skjold, T., Dahl, R., Juhl, B. and Sigsgaard, T. (2008) The Incidence of Respiratory Symptoms and Sensitisation in Baker Apprentices. European Respiratory Journal, 32, 452-459. http://dx.doi.org/10.1183/09031936.00108207

[36] Harris-Roberts, J., Robinson, E., Waterhouse, J.C., Billings, C.G., Proctor, A.R., Stocks-Greaves, M., Rahman, S., Evans, G., Garrod, A., Curran, A.D. and Fishwick, D. (2009) Sensitization to Wheat Flour and Enzymes and Associated Respiratory Symptoms in British Bakers. American Journal of Industrial Medicine, 52, 133-140. http://dx.doi.org/10.1002/ajim.20639

[37] Laraqui, O., Laraqui, S., Kanny, G., Verger, C., Caubet, A., Rkiek, B., Harourate, K., El Aoudi, Y., Bentayeb, N. and Laraqui, C. (2011) Prévalence des manifestations cliniques, des troubles fonctionnelles respiratoires et de la sensibilisation cutanée chez les artisans boulangers-pâtissiers à Casablanca. Revue Française d'Allergologie, 51, 10-21. http://dx.doi.org/10.1016/j.reval.2010.02.017

[38] Houba, R., Doekes, G. and Heederik, D. (1998) Occupational Respiratory Allergy in Bakery Workers: A Review of the Literature. American Journal of Industrial Medicine, 34, 529-546. http://dx.doi.org/10.1002/(SICI)1097-0274(199812)34:6<529::AID-AJIM1>3.0.CO;2-I

[39] Brisman, J., Järvholm, B. and Lillienberg, L. (2000) Exposure-Response Relations for Self Reported Asthma and Rhinitis in Bakers. Occupational and Environmental Medicine, 57, 335-340. http://dx.doi.org/10.1136/oem.57.5.335 
Scientific Research Publishing (SCIRP) is one of the largest Open Access journal publishers. It is currently publishing more than 200 open access, online, peer-reviewed journals covering a wide range of academic disciplines. SCIRP serves the worldwide academic communities and contributes to the progress and application of science with its publication.

Other selected journals from SCIRP are listed as below. Submit your manuscript to us via either submit@scirp.org or Online Submission Portal.
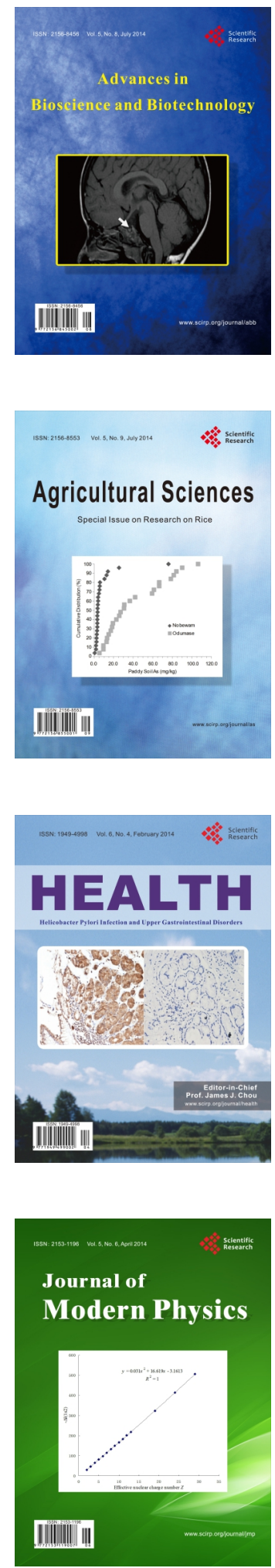
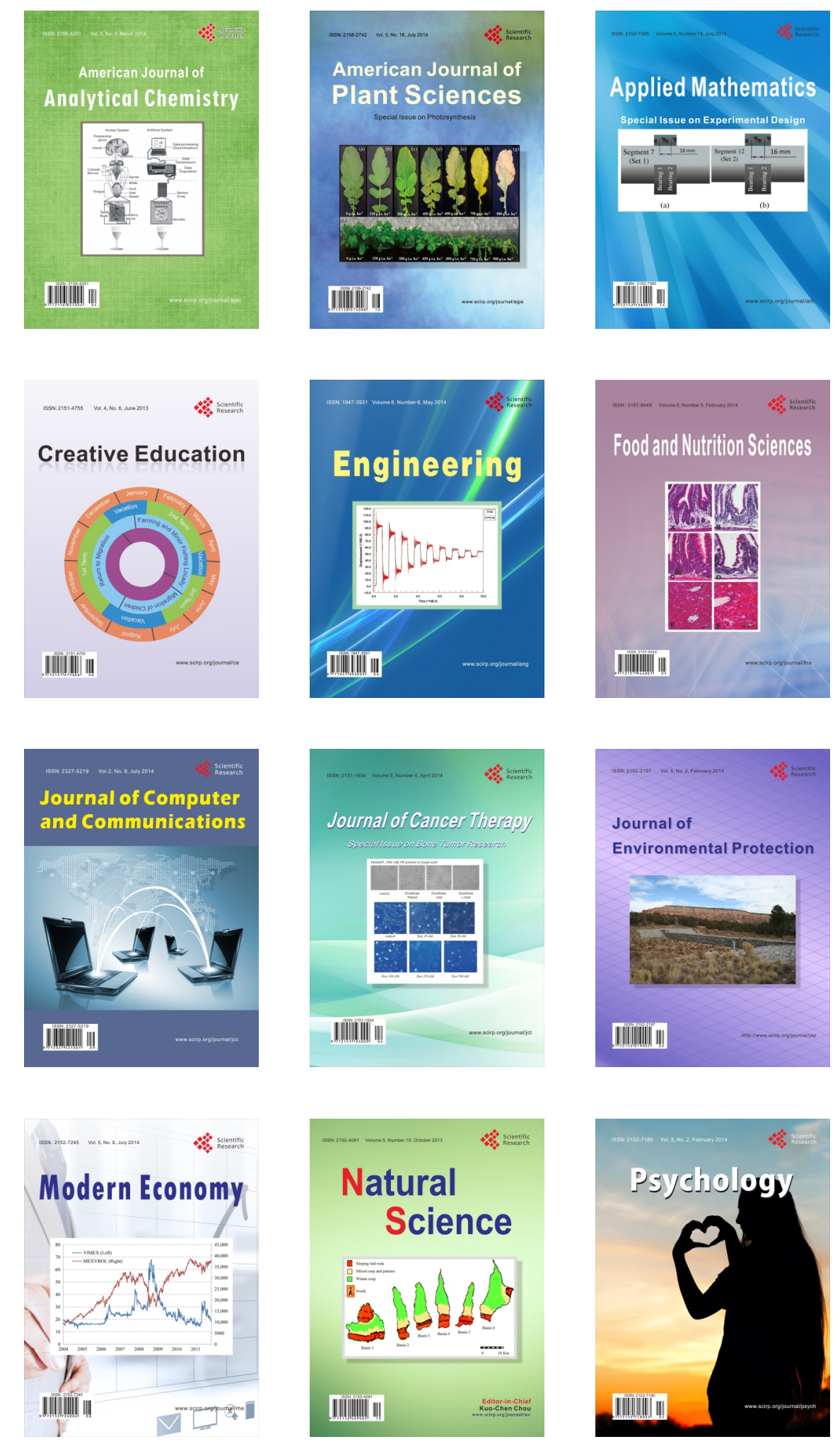